\title{
Pengaruh Lingkungan Kerja Terhadap Kinerja Pegawai MTs Taqwa Belitang
}

\author{
Ripda Erwin \\ STIE Trisna Negara, ripdaerwin@gmail.com
}

\begin{abstract}
ABSTRAK
Penelitian ini bertujuan untuk mengetahui pengaruh lingkungan kerja terhadap kinerja pegawai MTs Taqwa Belitang. Data yang diamati merupakan data lingkungan kerja dan data kinerja pegawai MTs Taqwa Belitang. Analisis data dan pembahasan dilakukan dengan menggunakan metode analsis kuantitatif yaitu dengan membandingkan hasil perhitungan lingkungan kerja dengan kinerja pegawai menggunakan teknik analisis data regresi linier sederhana. Hasil pembahasan didapat persamaan regresi linier sederhana yaitu $Y=10,346+0,772 X$. nilai konstanta sebesar 10,346 artinya lingkungan kerja $(X)$ nilainya adalah 0 , maka kinerja pegawai nilainya 10,346. Sedangkan koefisien regresi variabel lingkungan kerja $(X)$ sebesar 0,772 , artinya jika lingkungan kerja mengalami kenaikan sebesar 1, maka kinerja pegawai ( $\mathrm{Y}$ ) akan mengalami peningkatan sebesar 0,772. Koefisisen determinasinya $(\mathrm{R} 2)=0,811$ hal ini berarti korelasi variabel lingkungan kerja dengan kinerja pegawai adalah kuat, besarnya kontribusi ini dapat dilihat dri nilai $r 2=0,657$, yang berarti besar kontribusi variabel lingkungan kerja terhadap variabel kinerja pegawai adalah sebesar $65,7 \%$ sedangka sisanya di pengaruhi oleh variabel lain yang tidak termasuk dalam penelitian ini. Hasil pengujian hipotesis diperoleh thitung $=13,274$, dan ttabel $=2,0098$, berarti thitung lebih besar dari pada ttabel, dengan kata lain ada pengaruh yang signifikan variabel lingkungan kerja terhadap variabel kinerja pegawai. Karena terdapat pengaruh yang nyata antara variabel lingkungan kerja terhadap kinerja pegawai, maka lingkungan kerja pada MTs Taqwa Belitang perlu perhatikan lagi.
\end{abstract}

Kata Kunci : Lingkungan Kerja, Kinerja

\begin{abstract}
This study aims to determine the effect of the work environment on the performance of MTs Taqwa Belitang employees. The observed data are work environment data and performance data of MTs Taqwa Belitang employees. Data analysis and discussion was carried out using quantitative analysis methods, namely by comparing the results of the work environment calculations with employee performance using simple linear regression data analysis techniques. The results of the discussion obtained a simple linear regression equation that is $Y=10.346+0.772 X$. the constant value of 10.346 means that the work environment $(X)$ value is 0 , then the employee's performance is 10.346 . While the regression coefficient of the work environment variable $(X)$ is 0.772 , meaning that if the work environment increases by 1 , then the employee's performance $(Y)$ will increase by 0.772 . The coefficient of determination $(R 2)=0.811$ this means that the correlation of the work environment variable with employee performance is strong, the magnitude of this contribution can be seen from the value of $r 2=0.657$, which means that the contribution of the work environment variable to the employee performance variable is $65.7 \%$ while the rest is influenced by other variables not included in this study. The results of hypothesis testing obtained tcount $=13,274$, and ttable $=2.0098$, meaning that tcount is greater than ttable, in other words there is a significant effect of work environment variables on employee performance variables. Because there is a real influence between work environment variables on employee performance, the work environment at MTs Taqwa Belitang needs to be considered again.
\end{abstract}

Keywords: Work Environment, Performance

\section{A. PENDAHULUAN}

Sumber daya manusia mempunyai peranan penting untuk mewujudkan cita-cita perusahaan atau organisasi. Bila pegawai memiliki produktivitas dan motivasi kerja yang tinggi,maka laju roda perusahaan pun akan berjalan kencang,yang akhirnya akan menghasilkan kinerja dan pencapaian yang baik bagi perusahaan. Bagaimana mungkin roda perusahaan berjalan baik, bila pegawainya bekerja tidak produktif, 
artinya pegawai tidak memiliki semangat kerja yang tinggi,tidak ulet dalam bekerja dan memiliki moral yang rendah.

Seorang manajer yang efektif harus mahir dalam membaca tren dalam lingkungan external, dalam suatu pekerjaan serta memahami tren-tren tersebut berdampak pada suatu pekerjaan yang di laksanakannya dan tenaga kerja yang dikelola,lingkungan internal berpengaruh secara langsung terhadap kinerja dari sebuah organisas idengan internal tersebut meliputi pekerja, dewan komisaris, dan pemegang saham.

Manfaat lingkungan kerja adalah menciptakan gairah kerja, sehingga Produktivitas kerja meningkat. Sementara itu, manfaat yang di peroleh karena bekerja dengan orang-orang yang termotivasi adalah pekerjaan dapat di selesaikan dengan tepat. Artinya pekerjaan di selesaikan sesuai standar yang benar dan dalam skala waktu yang di tentukan.

Lingkungan kerja dalam suatu perusahaan atau organisasi sangatlah penting di perhatikan. Sebagai manajemen yang baik meskipun lingkungan kerja tidak melaksanakan proses produksi dalam suatu perusahaan,namun lingkungan kerja mempunyai pengaruh langsung terhadap para pegawai yang melaksanakan proses produksi tersebut, lingkungan kerja yang memusatkan diri pegawai tersebut dalam meningkatkan kinerja, sebaliknya lingkungan kerja yang tidak memadai dapat menurunkan kinerja pegawai yang pada akhirnya dapat menurunkan motivasi kerja pegawai.

Suatu kondisi lingkungan kerja dikatakan baik apabila dapat melaksanakan kegiatan secara optimal, sehat, nyaman dan aman. Lebih jauh lagi lingkungan kerja yang kurang baik dapat menyebabkan tidak efisiennya suatu rancangan sistem kerja, pola lingkungan kerja adalah pola tindakan organisasi yang mempengaruhi efektivitas organisasi secara langsung atau tidak langsung, yang meliputi kinerja dan produktivitas, dan perputaran, serta keanggotaan organisasi.

\section{B. KAJIAN TEORI}

1) Lingkungan Kerja

\section{Pengertian Lingkungan Kerja}

Lingkungan kerja dalam suatu perusahaan perlu diperhatikan, hal ini disebabkan karena lingkungan kerja mempunyai pengaruh langsung terhadap para pegawai. Lingkungan kerja yang kondusif dapat meningkatkan kinerja pegawai dan sebaliknya, lingkungan kerja yang tidak memadai akan dapat menurunkan kinerja pegawai. Kondisi lingkungan kerja dikatakan baik apabila manusia dapat melaksanakan kegiatan secara optimal, sehat, aman dan nyaman. Kesesuaian lingkungan kerja dapat dilihat akibatnya dalam jangka waktu yang lama. Lingkungan kerja yang kurang baik dapat menuntut tenaga kerja dan waktu yang lebih banyak dan tidak mendukung diperolehnya rancangan sistem kerja yang efisien.

Mangkunegara (2013:15) menyatakan lingkungan merupakan faktor yang mempengaruhi kinerja seseorang secara eksternal yang meliputi perilaku, sikap dan tindakan-tindakan, rekan kerja, bawahan atau pimpinan, fasilitas kerja dan iklim organisasi.

Menurut Sedarmayanti (2011:31) lingkungan kerja ada dua yaitu :

1. Lingkungan kerja fisik

Lingkungan kerja fisik adalah semua keadaan berbentuk fisik yang terdapat di sekitar tempat kerja yang dapat mempengaruhi pegawai baik secara langsung maupun secara tidak langsung. 


\section{Lingkungan kerja nonfisik}

Lingkungan kerja non fisik adalah semua keadaan yang terjadi berkaitan dengan hubungan kerja, baik hubungan dengan atasan maupun dengan rekan kerja, ataupun hubungan dengan bawahan.

Masalah lingkungan kerja dalam suatu organisasi sangatlah penting, dalam hal ini diperlukan adanya pengaturan maupun penataan faktor-faktor lingkungan kerja dalam penyelenggaraan aktivitas organisasi.

Sesuai dengan Keputusan Menteri Kesehatan No. 261/MENKES/SK/II/1998 tentang: Persyaratan Kesehatan Lingkungan Kerja bahwa lingkungan kerja perkantoran meliputi semua ruangan, halaman dan area sekelilingnya yang merupakan bagian atau yang berhubungan dengan tempat kerja untuk kegiatan perkantoran. Persyaratan kesehatan lingkungan kerja dalam keputusan ini diberlakukan baik terhadap kantor yang berdiri sendiri maupun yang berkelompok.

Sunyoto (2013:43), Lingkungan kerja merupakan bagian komponen yang sangat penting di dalam karyawan melakukan aktivitas bekerja. Dengan memperhatikan lingkungan kerja yang baik atau menciptakan kondisi kerja yang mampu memberikan motivasi untuk bekerja, maka akan membawa pengaruh terhadap kegairahan atau semangat karyawan bekerja.

Dari pendapat para ahli dapat disimpulkan bahwa lingkungan kerja adalah segala sesuatu yang ada disekitar pegawai pada saat bekerja baik berupa fisik maupun nonfisik yang dapat mempengaruhi pegawai saat bekerja. Jika lingkungan kerja yang kondusif maka pegawai bisa aman, nyaman dan jika lingkungan kerja tidak mendukung maka pegawai tidak bisa aman dan nyaman.

\section{Klasifikasi Lingkungan Perusahaan (Business Environment)}

Lingkungan perusahaan secara garis besar dapat di katagorikan ke dalam dua kelompok, yakni lingkungan eksternal (external environment) dan lingkungan dalam/internal perusahaan (internal envirotnment).

a) Lingkungan Eksternal Perusahaan

Menurut Sunyoto (2013:47) lingkungan eksternal perusahaan (external business environment) adalah berbagai faktor yang berada di luar organisasi yang harus di perhitungkan oleh organisasi perusahaan pada saat membuat keputusan.

Perusahaan perlu menghitungkan faktor-faktor yang berada di dalam lingkungan perusahaan karena faktor-faktor tersebut memiliki kekuatan (power) yang dapat mempengaruhi perusahaan. Perusahaan juga harus memperhitungkan berbagai perubahan yang terjadi di lingkungan eksternal perusahaan, karena lingkungan eksternal perusahaan dapat memberikan ancaman (threats) bagi berlangsungan jalannya perusahaan. Ancaman (threats) adalah berbagai kondisi di dalam lingkungan eksternal perusahaan yang dapat menghambat pencapaian tujuan perusahaan untuk memperoleh keungulan kompetitif.

b) Lingkungan Internal Perusahaan

Selain di pengaruhi oleh lingkungan eksternal perusahaan,perumusan misi dan tujuan perusahaan sangat di pengaruhi pula oleh lingkungan internal perusahaan. Berbagai faktor yang terdapat dalam lingkungan internal perusahaan (internal business environment) mencakup sumber daya (resources) dan kemampuan (capabilities). Baik sumber daya maupun kemampuan yang di miliki perusahaan saat ini akan membatasi misi, tujuan maupun strategi yang akan di buat oleh perusahan. Sebagai contoh, unilever sebagai pemimpin pasar consumer product di Indonesia 
memiliki berbagai sumbur daya dan kemampuan yang memungkinkan perusahaan memperoleh keunggulan kompetitif di bidang consumer product. Tetapi pada saat yang sama perusahaan ini tidak memiliki sumber daya maupun kemampuan di bidang usaha teknologi informasi karena bidang usaha teknologi informasi tidak tercakup dalam misi dan tujuan perusahaan.

\section{Faktor-faktor yang Mempengaruhi Lingkungan Kerja}

Menurut Sedarmayanti (2011:21) bahwa faktor-faktor yang dapat mempengaruhi terbentuknya lingkungan kerja adalah:

a. Penerangan/cahaya

Cahaya penerangan sangat besar manfaatnya bagi pegawai guna mendapat keselamatan dan kelancaran bekerja. Oleh sebab itu perlu di perhatikan adanya penerangan (cahaya) yang terang tetapi tidak menyilaukan.

b. Suhu Udara

Oksigen merupakan gas yang di butuhkan oleh mahluk hidup untuk menjaga kelangsungan hidup, yaitu untuk proses metabolisme. Udara di sekitar dikatakan kotor apabila kadar oksigen, dalam udara tersebut telah berkurang dan telah bercampur dengan gas atau bau-bauan yang berbahaya bagi kesehatan tubuh. Rasa sejuk dan segar dalam bekerja akan membantu mempercepat pemilihan tubuh akibat lelah setelah bekerja.

c. Suara Bising

Salah satu populasi yang cukup menyibukan para pakar untuk mengatasinya adalah kebisingannya, yaitu bunyi yang tidak dikehendaki oleh telinga.tidak dikehendaki, karena terutama dalam jangka panjang bunyi tersebut dapat menggangu ketenagan bekerja, merusak pendengaran dan menimbulkan kesalahan komunikasi, bahkan menurut penelitian, kebisingan yang serius bisa menyebabkan kematian. Karena pekerjaan membutuhkan konsentrasi, maka suara bising hendaknya dihindarkan agar pelaksanaan pekerjaan dapat dilakukan engan efisien sehingga produktivitas kerja meningkat.

d. Keamanan Kerja

Guna menjaga tempat dan kondisi lingkungan kerja tetap dalam keadaan aman maka perlu diperhatikan adanya keberadaanya. Salah satu upaya untuk menjaga keamanan di tempat kerja, dapat memanfaatkan tenaga satuan putugas keamanan (SATPAM)

e. Hubungan Pegawai

Lingkungan kerja yang menyenagkan bagi pegawai melalui pengikatan hubungan yang harmonis dengan atasan, rekan kerja, maupun bawahan serta didukung oleh sarana dan prasarana yang memadai yang ada di tempat bekerja akan membawa dampak yang positif bagi pegawai, sehingga kinerja pegawai dapat meningkat.

\section{Indikator - Indikator Lingkungan Kerja}

Menurut Sedarmayanti (2011), yang menjadi indikator-indikator lingkungan kerja adalah :
a. Penerangan
b. Suhu Udara
c. Suara Bising
d. Keamanan Kerja
e. Hubungan Karyawan 


\section{2) Kinerja}

\section{Pengertian Kinerja Pegawai}

Secara etimologi, kinerja berasal dari kata prestasi kerja (performance). Sebagaimana dikemukakan oleh Mangkunegara (2013:67) bahwa istilah kinerja berasal dari kata job performance atau actual performance (prestasi kerja atau prestasi sesungguhnya yang dicapai seseorang) yaitu hasil kerja secara kualitas dan kuantitas yang dicapai oleh seorang pegawai dalam melaksanakan tugasnya sesuai dengan tanggung jawab yang diberikan kepadanya. Lebih lanjut Mangkunegara (2013:75) menyatakan bahwa pada umumnya kinerja dibedakan menjadi dua, yaitu kinerja individu dan kinerja organisasi. Kinerja individu adalah hasil kerja karyawan baik dari segi kualitas maupun kuantitas berdasarkan standar kerja yang telah ditentukan, sedangkan kinerja organisasi adalah gabungan dari kinerja individu dengan kinerja kelompok.

Kinerja adalah sebagai cara untuk mengukur kontribusi pegawai kepada organisasi.dengan mengetahui kontribusi pegawai, maka selanjutnya dapat di gunakan sebagai upaya dapat menyusun program peningkatan kemampauan individu juga. Kinerja menurut Wibowo dalam Oktariansyah (2020:167) merupakan suatu proses tentang bagaimana pekerjaan berlangsung untuk mencapai hasil kerja.

Kinerja seseorang merupakan kombinasi dari kemampuan, usaha dan kesempatan yang dapat dinilai dari hasil kerjanya. Secara devinitif kinerja merupakan catatan out-come yang di hasilkan dari fungsi pegawai tertentu atau kegiatan yang di lakukan selama periode waktu tertentu.sedangkan kinerja suatu jabatan secara keseluruhan sama dengan jumlah (rata-rata) dari kinerja fungsi pegawai atau kegiatan yang di lakukan. Pengertian kinerja di sini tidak bermaksud menilai karakteristik individu tetapi mengacu pada serang-kaian hasil yang di peroleh selama periode waktu tertentu.

\section{Penilaian Kinerja}

Penilaian kinerja (performance appraisal) pada dasarnya merupakan salah satu faktor kunci guna mengembangkan suatu organisasi secara efektif dan efesien, karena adanya kebijakan atau program penilaian prestasi kerja, bearti organisasi telah memanfaatkan secara baik atas sumber daya mnusia yang ada dalam organisasi. Untuk keperluan penilaian kinerja pegawai publik, di perlukan adanya informasi yang relefan dan realiabel tentang prestasi kerja masing-masing individu.di samping informasi yang lengkap, informasi juga di harapkan berkualitas dan valid, artinya mampu mengambarkan kinerja pegawai secara baik.,di samping itu informasi tersebut juga di perlukan untuk perencanaan karir bagi mereka masing-masing. Penyedian informasi secara akurat, lengkap dan valid hanya dapat dilakukan jika ada sistem pengorganisasian informasi secara baik.dengan demikian untuk kebutuhan penilaian kinerja juga membutuhkan management information system (Sunyoto, 2013:87)

Penilaian kinerja merupakan suatu proses organisasi dalam menilai kinerja pegawainya.secara umum tujuan dari penilaian kinerja adalah memberika timbal balik kepada pegawai dalam upaya memperbaiki kerja pegawai dan untuk meningkatkan produktivitas organisasi.secara khusus tujuan penilaian kinerja adalah sebagai pertimbangan keputusan organisasi terhadap pegawainya mengenai promosi, mutasi, kenaikan gaji, pendidikan dan pelatihan ataupun kebijakan manajerial lainya, sehingga penilaian kinerja dapat menjadikan tolak ukur 
keberhasilan dari proses prekrutan, seleksi, penempatan dan pelatihan pada suatu organisasi.

\section{Tolak Ukur Keberhasilan Kinerja}

Menurut Rivai (2011:306) tolak ukur dari keberhasilan kinerja dapat di ukur sebagai berikut:

a. Kuantitas

Seberapa banyak target kerja logis yang ingin dicapai di bandingkan dengan kuantitatif aktualisasi.

b. Kualitas

Seberapa baik mutu hasil kerja yang ngin dicapai di bandingkan dengan realisasi,

c. Biaya

d. Waktu

waktu yang diperlukan agar sasaran kerja dapat dicapai

\section{Faktor-faktor yang Mempengaruhi Kinerja}

Untuk memperoleh kinerja yang tinggi dibutuhkan sikap mental yang memiliki pandangan jauh ke depan. Seseorang harus mempunyai sikap optimis, bahwa kualitas hidup dan kehidupan hari esok lebih baik dari hari ini.

Faktor yang turut mempengaruhi kinerja pegawai, yaitu ketrampilan interpersonal, mental untuk sukses, terbuka untuk berubah, kreativitas, trampil berkomunikasi, inisiatif, serta kemampuan dalam merencanakan dan mengorganisir kegiatan yang menjadi tugasnya. Faktor-faktor tersebut memang tidak langsung berhubungan dengan pekerjaan, namun memiliki bobot pengaruh yang sama.

Menurut Rivai (2011:324), dalam menilai kinerja seorang pegawai, maka diperlukan berbagai aspek penilaian antara lain pengetahuan tentang pekerjaan, kepemimpinan inisiatif, kualitas pekerjaan, kerjasama, pengambilan keputusan, kreativitas, dapat diandalkan, perencanaan, komunikasi, inteligensi (kecerdasan), pemecahan masalah, pendelegasian, sikap, usaha, motivasi, dan organisasi.

Selanjutnya, dari aspek-aspek penilaian kinerja yang dinilai tersebut selanjutnya dikelompokkan menjadi :

1) Kemampuan teknis, yaitu kemampuan menggunakan pengetahuan, metode, teknik, dan peralatan yang digunakan untuk melaksanakan tugas serta pengalaman dan pelatihan yang diperolehnya.

2) Kemampuan konseptual, yaitu kemampuan untuk memahami kompleksitas perusahaan dan penyesuaian bidang gerak dari unit masing-masing ke bidang operasional perusahaan secara menyeluruh. Pada intinya setiap individu atau karyawan pada setiap perusahaan memahami tugas, fungsi serta tanggungjwabnya sebagai seorang karyawan.

3) Kemampuan hubungan interpersonal, yaitu antara lain kemapuan untuk bekerja sama dengan orang lain, memotivasi karyawan, melakukan negosiasi, dan lainlain.

\section{METODE PENELITIAN}

Metode yang di gunakan adalah metode kuantitatif. Menurut Sugiyono (2015:12) Metode kuantitatif yaitu deskriftif gambaran, atau lukisan mengenai sifat- 
sifat maupun krakteristik dari objek penelitian yang dinyatakan dalam bentuk angka untuk memperjelas data.

\section{1) Populasi dan Sampel \\ $>$ Populasi}

Populasi merupakan keseluruhan subjek penelitian Arikunto (2013:173). Populasi diartikan sebagai wilayah generalisasi yang terdiri atas obyek/subyek yang mempunyai karakteristik tertentu yang ditetapkan oleh peneliti untuk di pelajari dan kemudian ditarik kesimpulannya. Adapun populasi dalam penelitian ini adalah seluruh pegawai MTs Taqwa Belitang yang berjumlah 94 orang.

\section{$>$ Sampel}

Sampel adalah sebagian atau wakil dari populasi yang diteliti Arikunto, (2013:174). Penelitian ini menggunakan teknik sampling jenuh. Sampling jenuh adalah teknik penentuan sampel bila semua anggota populasi digunakan sebagai sampel Sugiyono (2015:96). Hal ini sering dilakukan bila jumlah populasi relatif kecil, atau penelitian yang ingin membuat generalisasi dengan kesalahan yang sangat kecil. Sampel dalam penelitian ini adalah 94 Orang pegawai atau keseluruhan populasi.

\section{2) Teknik Pengumpulan Data}

Menurut Sugiyono (2015:199) ada beberapa teknik pengumpulan data yang dilakukan dalam penelitian ini adalah:

a. Observasi

Teknik observasi adalah kegiatan pengamatan,meliputi kegiatan pemusatan perhatian terhadap sesuatu objek yang mengunakan seluruh alat indera yang dapat dilakukan melalui indera pengelihatan, penciuman, pendengaran, peraba, dan pengecap. Observasi dilaksanakan dengan melakukan pengamatan secara langsung di kantor MTs Taqwa Belitang

b. Dokumentasi

Metode dokumentasi yaitu mencari data mengenal hal-hal atau variabel yang berupa catatan, transkip ,buku, surat kabar, majalah, prasasti, notulen rapat, lengger, agenda, dan sebagainya. Metode dokumentasi di gunakan untuk mengetahui struktur organisasi, tugas, dan kewajiban pegawai MTs Taqwa Belitang

c. Kuesioner

Kuesioner adalah metode pengumpulan data yang dilakukan dengan cara memberikan pertanyaan-pertanyaan kepada responden. Responden dalam penelitian ini adalah pegawai MTs Taqwa Belitang

\section{3) Teknik Analisis Data}

Teknik analisis data yang digunakan dalam penelitian ini adalah analisis kuantitif, yaitu suatu metode analisis yang menggunakan perhitungan angka-angka untuk pengmbilan keputusan, selanjutnya diolah menggunakan program SPSS versi 20.0 for windows.

\section{HASIL PENELITIAN}

1) Analisis Data

\section{Karakteristik Responden}

Berdasarkan Hasill pengumpulan data dan penyebaran kuisioner kepada pegawai MTs Taqwa Belitang yang menjadi responden, diketahui karakteristik setiap responden. 


\section{TABEL RESPONDEN BERDASARKAN JENIS KELAMIN}

\begin{tabular}{|c|c|c|}
\hline Jenis Kelamin & Frekuensi & Persentase (\%) \\
\hline Pria & 70 & 75 \\
Wanita & 24 & 25 \\
\hline Jumlah & 94 & 100 \\
\hline
\end{tabular}

Sumber: Hasil pengolahan Kuisioner

Dari tabel di atas memperlihatkan karakteristik responden berdasarkan jenis kelamin yang menunjukkan bahwa sebagian besar responden adalah pria yaitu sebangyak 70 orang atau $75 \%$

\section{Analisis Uji Validitas dan Reliabilitas}

Hasil uji validitas dan reliabilitas terhadap kuesioner yang disebarkan kepada 94 responden menunjukkan bahwa variabel Lingkungan Kerja (X), Kinerja Pegawai (Y) valid serta realibel untuk mengukur sikap subyek penelitian dan dapat disimpulkan bahwa alat ukur variabel Lingkungan Kerja (X), dan Kinerja Pegawai (Y) secara statistik dianggap mampu memberikan hasil pengukuran yang konsisten, apabila pengukuran dilakukan berulang-ulang.

\section{a) Uji Validitas}

Uji validitas digunakan untuk mengukur sah atau valid tidaknya suatu kuesioner, suatu kuesioner dikatakan valid jika pertanyaan pada kuesioner mampu untuk mengungkapkan suatu yang akan diukur oleh kuesioner tersebut Sugiyono, (2015:40). Dalam hal ini di gunakan beberapa butir pertanyaan yang dapat secara tepat mengungkapkan variabel yang diukur tersebut. Pengujian signifikasi terhadap kreteria validitas setiap butir instrument menggunakan program SPSS Versi 20.0.

1) Uji Validitas Variabel Lingkungan Kerja (X)

Menurut pendapat yang dikemukakan Priyatno (2015:90) dari output dapat diketahui nilai korelasi antara skor item $X$ (lingkungan kerja) dn skor total $Y$ (kinerja pegawai). Nilai ini kita bandingkan dengan $r_{\text {tabel}}, r_{\text {tabel }}$ dapat dicari pada signifikansi 0,05 dengan uji 2 sisi dan jumlh $\mathrm{n}=94$, maka di dapat rtabel sebesar 0,204 (dapat dilihat pada lampiran).

Uji validitas instrumen variabel lingkungan kerja yang diolah menggunakan SPSS versi 20.0 for windows diperoleh hasil pada tabel beikut.

TABEL HASIL UJI VALIDITAS VARIABEL LINGKUNGAN KERJA

\begin{tabular}{|c|c|c|c|}
\hline No Butir Instrumen & $\mathbf{r}_{\text {hithg }}$ & $\mathbf{r}_{\text {tabel }}$ & Keterangan \\
\hline $\mathbf{1}$ & 0.621 & $\mathbf{0 . 2 0 4}$ & Valid \\
\hline $\mathbf{2}$ & 0.485 & $\mathbf{0 . 2 0 4}$ & Valid \\
\hline $\mathbf{3}$ & 0.740 & $\mathbf{0 . 2 0 4}$ & Valid \\
\hline $\mathbf{4}$ & 0.380 & $\mathbf{0 . 2 0 4}$ & Valid \\
\hline $\mathbf{5}$ & 0.434 & $\mathbf{0 . 2 0 4}$ & Valid \\
\hline $\mathbf{6}$ & 0.394 & $\mathbf{0 . 2 0 4}$ & Valid \\
\hline $\mathbf{7}$ & 0.494 & $\mathbf{0 . 2 0 4}$ & Valid \\
\hline $\mathbf{8}$ & 0.581 & $\mathbf{0 . 2 0 4}$ & Valid \\
\hline $\mathbf{9}$ & 0.537 & $\mathbf{0 . 2 0 4}$ & Valid \\
\hline $\mathbf{1 0}$ & 0.613 & $\mathbf{0 . 2 0 4}$ & Valid \\
\hline
\end{tabular}

Sumber : Data Primer yang diolah SPSS ver. 20.0 
Data uji instrumen yang diperoleh dari 94 orang responden dianalisis menggunakan bantuan program SPSS Versi 20.0 for windows diperoleh nilai hasil uji validitas dari 10 item pertanyaan variabel lingkungan kerja $(X)$ pada taraf nyata 5\%, semua iem nilai korelasi yang diperoleh lebih besar dari 0, 204 sehingga seluruh butir pertanyaan untuk variabel lingkungan kerja (X) dinyatakan valid. Berarti seluruh item pertanyaan yang terdapat dalam butir instrumen tersebut dapat dijadikan sebagai alat ukur yang valid dalam analsis selanjutnya.

2) Uji Validitas Variabel Kinerja Pegawai (Y)

Uji validitas instrumen variabel kinerja pegawai yang diolah menggunakan SPSS versi 20.0 for windows diperoleh hasil pada tabel berikut :

\section{TABEL HASIL UJI VALIDITAS VARIABEL KINERJA PEGAWAI}

\begin{tabular}{|c|c|c|c|}
\hline No Butir Instrumen & $\mathbf{r}_{\text {hitung }}$ & $\mathbf{r}_{\text {tabel }}$ & Keterangan \\
\hline $\mathbf{1}$ & 0.497 & $\mathbf{0 . 2 0 4}$ & Valid \\
\hline $\mathbf{2}$ & 0.464 & $\mathbf{0 . 2 0 4}$ & Valid \\
\hline $\mathbf{3}$ & 0.724 & $\mathbf{0 . 2 0 4}$ & Valid \\
\hline $\mathbf{4}$ & 0.802 & $\mathbf{0 . 2 0 4}$ & Valid \\
\hline $\mathbf{5}$ & 0.829 & $\mathbf{0 . 2 0 4}$ & Valid \\
\hline $\mathbf{6}$ & 0.898 & $\mathbf{0 . 2 0 4}$ & Valid \\
\hline $\mathbf{7}$ & 0.800 & $\mathbf{0 . 2 0 4}$ & Valid \\
\hline $\mathbf{8}$ & 0.468 & $\mathbf{0 . 2 0 4}$ & Valid \\
\hline $\mathbf{9}$ & 0.498 & $\mathbf{0 . 2 0 4}$ & Valid \\
\hline $\mathbf{1 0}$ & 0.487 & $\mathbf{0 . 2 0 4}$ & Valid \\
\hline
\end{tabular}

Sumber : Data Primer yang diolah SPSS ver. 20.0

Dari tabel diatas, data uji instrumen yang diperoleh dari 94 orang responden dianalisis menggunakan bantuan program SPSS Versi 20.0 for windows diperoleh nilai hasil uji validitas dari 10 item pertanyaan variabel kinerja pegawai $(X)$ pada taraf nyata $5 \%$, semua item nilai korelasi yang diperoleh lebih besar dari 0,204 sehingga seluruh butir pertanyaan untuk variabel kinerja pegawai $(\mathrm{X})$ dinyatakan valid. Berarti seluruh item pertanyaan yang terdapat dalam butir instrumen tersebut dapat dijadikan sebagai alat ukur yang valid dalam analsis selanjutnya.

\section{b) Uji Reliabilitas}

Uji reliabilitas merupakan alat untuk mengukur suatu kuesioner yang merupakan indikator dari variabel atau konstruk. Suatu kuesioner dikatakan reliable atau handal jika jawaban seseorang terhadap pernyataan adalah konsisten atau stabil dari waktu ke waktu.

Selain itu, Sugiyono (2015:149) menyatakan reliabilitas merupakan indeks yang menunjukan sejauh mana suatu alat pengukur dapat di percaya atau dapat diandalkan. Instrumen yang baik tidak akan bersifat tendensius atau mengarahkan responden untuk memilih jawaban-jawaban tertentu. Instrumen yang sudah dapat dipercaya, yang reliabel akan menghasilkan data yang dapat dipercaya. 
Reliabilitas untuk mengetahui seberapa tingkat konsistensi internal (intenal consistency) jawaban responden terhadap instrumen untuk mengukur variabel lingkungan kerja dan kinerja pegawai.

Untuk menguji reliabilitas seluruh item - item pertanyaan variabel lingkungan kerja $(\mathrm{X})$ dan variabel kinerja pegawai $(\mathrm{Y})$ penulis menggunakan Alpha Cronbach's., Tingkat reabilitas dengan metoe alpha cronbach, diukur dengan sekala alpha cronbach 0 sampai 1. Apabila skla tersebut dikelompokkan dengan range yang sama.

Uji reliebilitas yang di gunakan dalam penelitian ini adala metode cronbach's alpha melalui program SPSS versi 20.0.

Nilai reliabilitas kurang dari 0,6 adalah kurang baik, sedangkan 0,7 dapat diterima dan di atas 0,8 adalah baik (Priyatno, 2015:98).

TABEL NILAI RELIABILITAS

\begin{tabular}{ccc}
\hline No & Nilai Reliabilitas & Tingkatan \\
\hline $\mathbf{1}$ & 0,6 & Kurang Baik \\
$\mathbf{2}$ & 0,7 & Sedang \\
$\mathbf{3}$ & 0,8 & Baik \\
\hline \multicolumn{2}{l}{ Sumber : Priyatno, (2010:98) } & \\
\hline
\end{tabular}

1. Uji Reliabilitas Variabel Lingkungan Kerja (X)

Uji reliabilitas variabel lingkungan kerja yang diolah menggunakan SPSS Versi 20.0 for Windows diperoleh hasil pada tabel berikut:

\section{TABEL UJI RELIABILITAS VARIABEL LINGKUNGAN KERJA}

\begin{tabular}{lll}
\hline $\begin{array}{l}\text { Cronbach's } \\
\text { Alpha }\end{array}$ & $\mathrm{N}$ of Items N of Items & Hasil Reliabilitas \\
\hline $\mathbf{8 2 7}$ & 10 & Reliabel \\
\hline
\end{tabular}

Sumber : Data Primer yang diolah SPSS ver. 20.0

Dari tabel diatas diperoleh nilai Cronbach's Alpha sebesar 0,827 >0,6. Karena nilai di atas 0,6 maka dapat disimpulkan bahwa alat ukur dalam penelitian ini dinyatakan reliabilitas dan dapat dijadikan alat ukur analisis data selanjutnya.

2. Uji Reliabilitas Variabel Kinerja Pegawai $(Y)$

Uji reliabilitas variabel lingkungan kerja yang diolah menggunakan SPSS Versi 20.0 for Windows diperoleh hasil pada tabel berikut:

\section{TABEL UJI RELIABILITAS VARIABEL KINERJA PEGAWAI}

\begin{tabular}{llc}
\hline $\begin{array}{l}\text { Cronbach's } \\
\text { Alpha }\end{array}$ & $\begin{array}{l}\mathrm{N} \text { of Items } \mathrm{N} \text { of } \\
\text { Items }\end{array}$ \\
\hline .896 & 10 & Reliabel \\
\hline Sumber : Data Primer yang diolah SPSS ver. 20.0
\end{tabular}

Dari tabel diatas diperoleh nilai Cronbach's Alpha sebesar 0,896>0,6. Karena nilai di atas 0,6 maka dapat disimpulkan bahwa alat ukur dalam penelitian ini dinyatakan reliabel dan dapat dijadikan alat ukur analisis data selanjutnya. 
TABEL REKAPITULASI UJI RELIABILITAS

\begin{tabular}{llll}
\hline Variabel & $\begin{array}{l}\text { Cronbach's } \\
\text { Alpha Item }\end{array}$ & $\begin{array}{l}\text { Cronbach's } \\
\text { Alpha }\end{array}$ & Keterangan \\
\hline Lingkungan Kerja $(\mathbf{X})$ & 0.827 & 0,6 & Reliabel \\
\hline Kinerja Pegawai (Y) & $\mathbf{0 . 8 9 6}$ & $\mathbf{0 , 6}$ & Reliabel \\
\hline Sumber : Data Primer yang diolah SPSS Versi & $\mathbf{2 0}, 0$ &
\end{tabular}

Sumber : Data Primer yang diolah SPSS Versi 20.0

Dilihat dari hasil pengujian data yang dilakukan dengan bantuan Program SPSS versi 20.0, Cronbach's Alpha item variabel diperoleh masing-masing 0,827 dan 0,896, maka dapat disimpulkan untuk kedua variabel Cronbach's Alpha item $\geq$ nilai Cronbach's Alpha, maka dapat disimpulkan semua item pertanyaan yang ada pada instrumen tersebut dapat dijadikan sebagai alat ukur yang reliabel dan dapat digunakan untuk analisis selanjutnya.

\section{Analisis Regresi Sederhana}

Anlisis regresi lenier sederhana menggunakan SPSS Versi 20.0 for windows yaitu dengan hasil sebagai berikut:

TABEL HASIL UJI REGRESI LINIER SEDERHANA

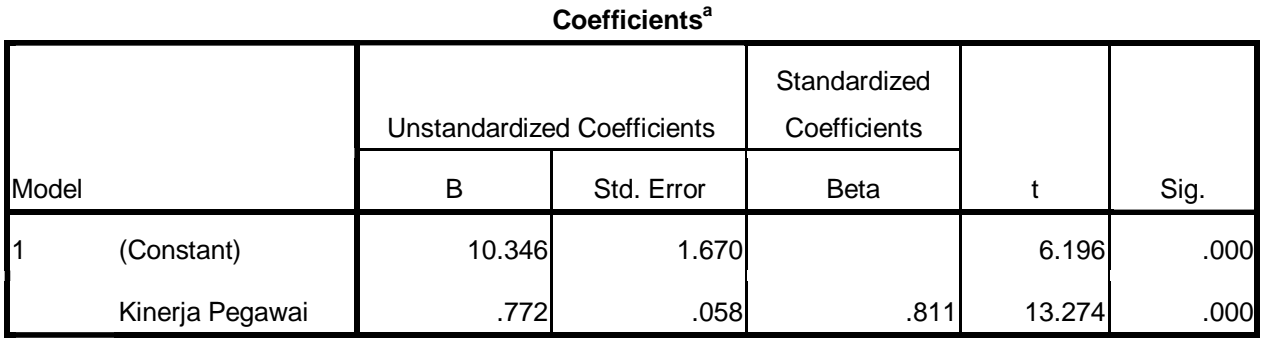

a. Dependent Variable: Lingkungan Kerja

Berdasarkan data di atas diperoleh persamaan regresinya sebagai berikut:

$Y^{\prime}=a+b X$

$Y=10,346+0,772 X$

persamaan regresi tersebut diperoleh nilai konstanta sebesar 10,346 artinya lingkungan kerja $(X)$ nilainya adalah 0 , maka kinerja pegawai nilainya 10,346. Sedangkan koefisien regresi variabel lingkungan kerja $(X)$ sebesar 0,772 , artinya jika lingkungan kerja mengalami kenaikan sebesar 1, maka kinerja pegawai $(\mathrm{Y})$ akan mengalami peningkatan sebesar 0,772 .

\section{Analisis Koefisien Korelasi Sederhana}

\section{TABEL MODEL SUMMARY}

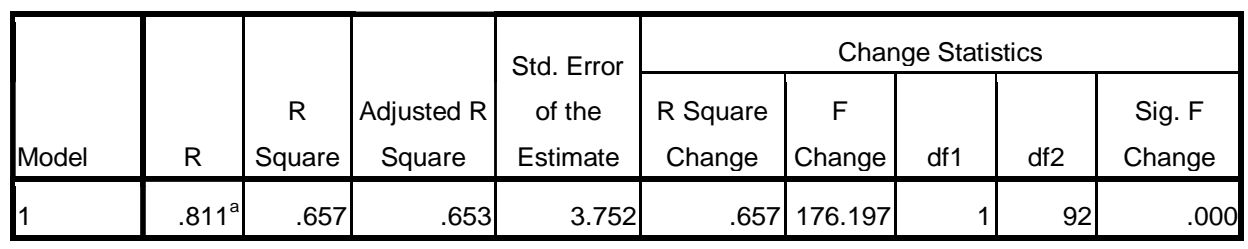

a. Predictors: (Constant), Kinerja Pegawai

Menurut Sugiyono (2015:85) pedoman untuk memberikan interprestasi koefisien korelasi sebagai berikut: 
TABEL INTERPRETASI KOEFISIEN KORELASI

\begin{tabular}{cc}
\hline Interprestasi Koefisien & Tingkat Hubungan \\
\hline $\mathbf{0 , 0 0 - 0 , 1 9 9}$ & Sangat rendah \\
$\mathbf{0 , 2 0}-\mathbf{0 , 3 9 9}$ & Rendah \\
$\mathbf{0 , 4 0}-\mathbf{0 , 5 9 9}$ & Sedang \\
$\mathbf{0 , 6 0}-\mathbf{0 , 7 9 9}$ & Kuat \\
$\mathbf{0 , 8 0 - 1 , 0 0 0}$ & Sangat kuat \\
\hline
\end{tabular}

Sumber : Sugiyono (2013)

Nilai korelasi sederhana dari tabel diatas adalah $\mathrm{R}=0,811$ artinya korelasi hubungan variabel lingkungan kerja dengan kinerja pegawai adalah sangat kuat.

\section{Uji Hipotesis}

Pengujian hipotesis digunakan untuk memperkuat hasil perhitungan yaitu dengan menggunakan nilai $t$. Uji $t$ dilakukan untuk mengetahui ada tidaknya pengaruh yang signifikan antara dua variabel. Menurut Priyatno (2015:58) uji t digunakan untuk mengetahui apakah variabel independent $(\mathrm{X})$ berpengaruh secara signifikan terhadap variabel dependen (Y). Signifikan artinya berarti atau berpengaruh, yang terjadi dapat berlaku populasi. Analisis menggunakan program SPSS Versi 20.0 untuk mencari persamaan regresi dengan kreteria sebagai berikut:

Setelah diperoleh regresi hasil perhitungan koefisien korelasi antara lingkungan kerja dan kinerja pegawai, selanjutnya dilakukan uji hipotesis dengan langkahlangkah sebagai berikut:

1) Menentukan Hipotesis

Ho : Tidak ada pengaruh yang signifikan antara lingkungan kerja terhadap kinerja pegawai MTs Taqwa Belitang

$\mathrm{Ha}$ : Ada pengaruh yang signifikan antara lingkungan kerja terhadap kinerja pegawai MTs Taqwa Belitang

2) Menentukan taraf nyata $(\alpha)$

Taraf nyata atau nilai tabel ditentukan degan derajat bebas (df) $\mathrm{df}=\mathrm{n}-2$

Taraf nyata dengan $\alpha=5 \%$ atau 0,05 dengan derajat kebebasan $\mathrm{df}=94=2=$ 92

Karena 92 pada tabel t terletak diantara 60 dan 120, maka untuk mencari ttabel menggunakan rumus Interpolasi:

$$
C=C_{0}+\frac{\left(C_{1}-C_{0}\right)}{\left(B_{1}-B_{0}\right)} \cdot\left(B-B_{0}\right)
$$

Dimana:

$\mathrm{B} \quad=$ Nilai $\mathrm{dk}$ yang dicari

B0 = Nilai $\mathrm{dk}$ pada awal nilai yang sudah ada

B1 = Nilai dk pada akhir nilai yang sudah ada

$\mathrm{C}=$ Nilai tabel yang dicari

Co = Nilai tabel yang pada awal nilai yang sudah ada

C1 = Nilai tabel yang pada akhir nilai yang sudah ada

B $\quad=\mathrm{df}=94-2=92$

BO $=60$

$\mathrm{B} 1=120$

$\mathrm{CO}=2,021$

C1 $=2,000$ 


$$
\begin{aligned}
& C=2,021+\frac{(2,000-2,021)}{(120-60)} \cdot(92-60) \\
& C=2,021+\frac{(-0,021)}{(60)} \cdot(32) \\
& C=2,021+\frac{(-0,021)}{(60)} \cdot(32) \\
& C=2,021+(-0,0112) \\
& C=2,021+(-0,0112) \\
& C=2,0098 \\
& \text { Jadi ttabel adalah } 2,0098
\end{aligned}
$$

3) Menentukan Kriteria Pengujian Hipotesis

Ho diterima jika $P$-value $>5 \%$ atau $t_{\text {hit }}<t_{\text {tab }}$

Ho ditolak jika $P$-value $<5 \%$ atau $t_{\text {hit }}>t_{\text {tab }}$

- Ho diterima Ha ditolak jika thitung > ttabel, artinya bahwa tidak ada pengaruh signifikan antara lingkungan kerja terhadap kinerja pegawai MTs

\begin{tabular}{|c|c|c|c|c|c|c|}
\hline \multirow{2}{*}{\multicolumn{2}{|c|}{ Model }} & \multicolumn{2}{|c|}{$\begin{array}{l}\text { Unstandardized } \\
\text { Coefficients }\end{array}$} & \multirow{2}{*}{\begin{tabular}{|l} 
Standardized \\
Coefficients \\
Beta \\
\end{tabular}} & \multirow[b]{2}{*}{$\mathrm{t}$} & \multirow[b]{2}{*}{ Sig. } \\
\hline & & $B$ & Std. Error & & & \\
\hline \multirow[t]{2}{*}{1} & (Constant) & 10.346 & 1.670 & & 6.196 & .000 \\
\hline & Kinerja Pegawai & .772 & .058 & .811 & 13.274 & .000 \\
\hline
\end{tabular}
Taqwa Belitang.

- Ho ditolak Ha diterima jika thitung $<t_{\text {tabel, }}$ artinya bawa ada pengaruh signifikan antara lingkungan kerja terhadap kinerja pegawai MTs Taqwa Belitang.

4) Uji Statistik

TABEL COEFISIENTS

a. Dependent Variable: Lingkungan Kerja

Berdasarkan tabel di atas, diperoleh thitung $=13,274$, berarti $t_{\text {hitung lebih besar }}$ dari pada tabel, dengan kata lain ada pengaruh yang signifikan variabel lingkungan kerja terhadap variabel kinerja pegawai.

Kesimpulan

> Apabila nilai $P$-value $>5 \%$, maka Ho diterima dan Ha ditolak, artinya bahwa tidak ada pengaruh yang signifikan lingkungan kerja terhadap kinerja pegawai MTs Taqwa Belitang

> Apabila nilai $P$-value $>5 \%$, maka Ho ditolak dan Ha diterima, artinya bahwa ada pengaruh yang signifikan lingkungan kerja terhadap kinerja pegawai MTs Taqwa Belitang

\section{E. PEMBAHASAN}

Berdasarkan hasil perhitungan persamaan regresi linier sederhana di peroleh $Y$ $=10,346+0,772 X$. nilai konstanta sebesar 10,346 artinya lingkungan kerja $(X)$ nilainya adalah 0 , maka kinerja pegawai nilainya 10,346. Sedangkan koefisien regresi variabel lingkungan kerja $(X)$ sebesar 0,772 , artinya jika lingkungan kerja 
mengalami kenaikan sebesar 1, maka kinerja pegawai $(Y)$ akan mengalami peningkatan sebesar 0,772 .

Koefisisen determinasinya $(\mathrm{R} 2)=0,811$ hal ini berarti korelasi variabel lingkungan kerja dengan kinerja pegawai adalah kuat, besarnya kontribusi ini dapat dilihat dri nilai $r 2=0,657$, yang berarti besar kontribusi variabel lingkungan kerja terhadap variabel kinerja pegawai adalah sebesar $65,7 \%$ sedangka sisanya di pengaruhi oleh variabel lain yang tidak termasuk dalam penelitian ini.

Berdasarkan hasil pengujian hipotesis diperoleh $t_{\text {hitung }}=13,274$, dan tabel $=$ 2,0098, berarti thitung lebih besar dari pada ttabel, dengan kata lain ada pengaruh yang signifikan variabel lingkungan kerja terhadap variabel kinerja pegawai.

\section{F. KESIMPULAN DAN SARAN}

\section{Kesimpulan}

Adapun kesimpulan yang dapat diberikan sehubungan dengan hasil penelitian dan pembahasan ini dapat diuraikan sebagai berikut :

1. Berdasarkan hasil perhitungan persamaan regresi linier sederhana di peroleh $Y$ $=10,346+0,772 X$. nilai konstanta sebesar 10,346 artinya lingkungan kerja $(X)$ nilainya adalah 0 , maka kinerja pegawai nilainya 10,346 . Sedangkan koefisien regresi variabel lingkungan kerja $(X)$ sebesar 0,772 , artinya jika lingkungan kerja mengalami kenaikan sebesar 1, maka kinerja pegawai (Y) akan mengalami peningkatan sebesar 0,772.

2. Koefisisen determinasinya $(\mathrm{R} 2)=0,811$ hal ini berarti korelasi variabel lingkungan kerja dengan kinerja pegawai adalah kuat, besarnya kontribusi ini dapat dilihat dri nilai $r 2=0,657$, yang berarti besar kontribusi variabel lingkungan kerja terhadap variabel kinerja pegawai adalah sebesar $65,7 \%$ sedangka sisanya di pengaruhi oleh variabel lain yang tidak termasuk dalam penelitian ini.

3. Pengujian hipotesis diperoleh $t_{\text {hitung }}=13,274$, dan $t_{\text {tabel }}=2,0098$, berarti thitung lebih besar dari pada tabel, dengan kata lain ada pengaruh yang signifikan variabel lingkungan kerja terhadap variabel kinerja pegawai.

\section{Saran}

Dari hasil analisis dan pembahasan serta kesimpulan yang telah dikemukakan, maka saran-saran yang dapat diberikan dari hasil penelitian ini yaitu sebagai berikut :

1. Mengingat kontribusi terhadap kinerja karyawan dari faktor yang diamati dalam penelitian ini sudah cukup besar $(65,7 \%)$ maka perlu adanya penambahan variabel penelitian untuk menghasilkan semua faktor yang berpengaruh terhadap kinerja pegawai sehingga dapat meningkatkan nilai koefisien determinasi.

2. Karena terdapat pengaruh yang nyata antara variabel lingkungan kerja terhadap kinerja pegawai, maka lingkungan kerja pada kantor MTs Taqwa Belitang perlu perhatikan lagi.

\section{DAFTAR PUSTAKA}

Arikunto, Suharsimi. (2013). Prosedur Penelitian Suatu Pendekatan Praktik. Edisi Revisi. Jakarta - RenikaCipta. 
Mangkunegara (2013). Manajemen Sumber Daya Manusia Perusahaan. Cetakan ke11. Bandung: Remaja Rosdakarya.

Oktariansyah. (2020). Pengaruh Karakteristik Individual dan Lingkungan Kerja Terhadap Kinerja Pegawai Kantor Dinas Transmigrasi Kabupaten Banyuasin. Jurnal Media Wahana Ekonomika. Vol 17 No 2. Juli 2020. Halaman 167

Priyatno, Duwi. (2015). SPSS 20 Pengolahan Data Terpraktis. Yogyakarta: Andi Offset.

Rivai, Veitzhal. (2011). Manajemen Sumber Daya Manusia untuk Perusahaan. Jakarta, Indonesia: Rajawali Pers.

Sugiyono. (2015). Metode Penelitian Bisnis (MPB), Penerbit Alfabeta, Bandung.

Sunyoto, Danang. (2013). Sumber Daya Manusia: Teori, Kuisoner, Dan Analisis Data, Penerbit Caps (Center For Academic Publishing Service), Yogyakarta.

Sunyoto, Danang. (2015). Penelitian Sumber Daya Manusia. Jakarta, Indonesia: CAPS (Center of Academic Publishing Service).

Sedarmayanti. (2011). Tata Kerja dan Produktivitas Kerja (Suatu Tinjauan dari Aspek Ekonomi Antara Manusia dengan Lingkungan Kerjanya). Bandung: CV. Mandar Maju. 